\title{
From firsts to the future
}

\author{
Lawrence H. Cohn, MD
}

The year 2011 celebrates many firsts in the cardiothoracic surgical community. It was 80 years ago this October that The Journal of Thoracic and Cardiovascular Surgery, the first in the field, was published by Evarts Graham, who performed the first successful pneumonectomy. Dr Graham ran the Journal for 26 years, making it one of the most prominent medical journals in the world.

The year 2011 is also significant for women in thoracic surgery. In 1961, 50 years ago, Nina Starr Braunwald became the first woman to be certified by the American Board of Thoracic Surgery and later became the first woman member of the American Association for Thoracic Surgery (AATS). During this time, Dr Braunwald was a staff member of the National Institutes of Health, under the guidance of Andrew Morrow, where she performed the first successful prosthetic mitral valve replacement. This operation was performed with a "homemade device" made of flexible open-cell polyurethane with Teflon chordae tendineae. Nina's many firsts have enhanced the field of cardiothoracic surgery, and currently there are 200 woman certified by the American Board of Thoracic Surgery.

On the cover of this issue is a photograph of the first successful heart-lung transplant performed in the world by Drs Shumway and Reitz. March marked the 30th anniversary of this historic operation, which has extended the lives of many patients with combined heart disease and severe pulmonary hypertension. Bruce Reitz has summarized his experience with this historic double-organ transplant nicely and it is published in the section titled "Reflections of the Pioneers." I think you will find it extremely engaging.

Beginning with this issue and continuing until the Centennial Celebration of the AATS in 2017, we will begin the publication of our Presidential Perspectives, under the direction of Marc Moon, MD, and the Centennial Committee of the AATS. These reflections will provide insight into the varying paths through which former AATS presidents have traveled to reach the ultimate leadership position in our specialty, as well as document their contributions to our field. This is an exciting project in anticipation of the Centennial celebration in 2017.

At the recent Society of Thoracic Surgeons Meeting in San Diego, the Joint Council on Thoracic Surgical Educa-

\footnotetext{
From the Division of Cardiac Surgery, Brigham and Women's Hospital, Boston, Mass.

Address for reprints: Lawrence H. Cohn, MD, Division of Cardiac Surgery, Brigham and Women's Hospital, 75 Francis St, Boston, MA 02115 (E-mail: lcohn@ partners.org).

J Thorac Cardiovasc Surg 2011;141:861-2

$0022-5223 / \$ 36.00$

Copyright (C) 2011 by The American Association for Thoracic Surgery doi:10.1016/j.jtcvs.2011.02.001
}

tion, under the direction of Edward Verrier, MD, held an educational "Think Tank": Organization and Use of Electronic Thoracic Surgery Educational Content. This session was very well attended by the leaders of the various educational venues of our specialty, including the American Board of Thoracic Surgery and the Thoracic Surgery Directors Association. It is central to our specialty to agree on one platform regarding the educational aspect of cardiothoracic surgery because as I have said before, "the times they are a changing," particularly in terms of learning and implementing new technologies traditionally treated in a more conservative manner.

The increased interest in education and re-education at all levels has stimulated me to introduce a new section in the Journal, titled "Cardiothoracic Surgical Training and Education." This section will contain peer-reviewed articles based on educational tools to train all levels of cardiothoracic surgeons in new technologies and techniques becoming commonplace throughout the world. A quotation I like to use that I believe will be important to all of us as the field of cardiothoracic surgery continues to explode is, "Don't be afraid to do a new procedure, but be aware that technology is sometimes more advanced than our ability to apply it properly." We need to understand the best options available to our patients and how to master the skills to apply these techniques without an "extended" learning curve. I believe The Journal of Thoracic and Cardiovascular Surgery is an excellent place to highlight these new skills.

One of the first articles to be published in this section will be one by David Jones, MD, Chairman of the Research Committee of the Thoracic Surgery Foundation for Research and Education (TSFRE). Dr Jones has surveyed all recipients of TSFRE research grants and fellowships and has compiled an impressive list of the academic achievements of this selective group of young cardiothoracic surgeons. It is essential for us to understand the significance of these grants and fellowships provided by the TSFRE, because they have been a great stimulus for our young academic cardiothoracic surgeons, researchers, and mentors. The TSFRE was founded by the AATS, Society of Thoracic Surgeons, Southern Thoracic Surgical Association, and Western Thoracic Surgical Association, and is a bedrock for the future of cardiothoracic surgical and research trainees.

As another important extension in the education of our cardiothoracic residents, I would like to thank Edwards Lifesciences, Corp (Irvine, Calif), for providing a subscription to The Journal of Thoracic and Cardiovascular Surgery for every resident in Accreditation Council for Graduate Medical Education training programs in the United States. 
This is an excellent exercise and one that will assist our residents in keeping pace with the current literature in print and online. We thank Edwards Lifesciences, Corp, for their interest in the future of our specialty.

I also thank Craig Smith, MD, for his commitment to the Journal these past 3 years. Craig will be stepping down as Associate Editor of "Acquired Cardiovascular Disease" this May as he focuses on his responsibilities as President of the AATS, as well as his many clinical and administrative responsibilities at Columbia. Craig has done an outstanding job during his tenure as an Associate Editor while balancing an extremely busy schedule, and he is to be congratulated. Dr John Ikonomidis will assume Craig's role as Associate Editor of "Acquired Cardiovascular Disease," along with Hartzell Schaff, MD. John has been the top Editorial Board
Reviewer for several years now, and I have no doubt he will continue the outstanding intellectual commitment he has made to the Journal. I am looking forward to working with John in his new role as Associate Editor.

Finally, I would like to pay special tribute to Martin McKneally, MD, who is retiring from his role as Ethics Editor after 10 years of hard work and dedication to this important aspect of the Journal. During the last few years, more attention has been paid to conflict of interest for all physicians, and especially cardiothoracic surgeons, who are on the cutting edge of new technology. Marty has done a superb job and has always been fair and consistent in the handling of the ethical issues presented to The Journal of Thoracic and Cardiovascular Surgery. Thank you, Marty, for a job well done. 